ISSN 1991- 8690

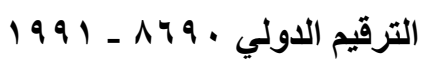

website:http://jsci.utq.edu.iq

Email:utjsci@utq.edu.iq

\title{
Synthesis of Some new Sulfonamide Schiff's Bases and Study Their Gastroprotective
}

\section{Activity}

\author{
Faeza A. Almashal ${ }^{1} \quad{ }^{*}$ Usama H. Ramadhan ${ }^{2} \quad$ Ahmed Majeed Jassem $^{1}$
}

${ }^{1}$ Department of Chemistry- College of Education-University of Basrah. Basrah-Iraq

${ }^{2}$ Department of pharmaceutical chemistry, College of pharmacy, University of Basrah, Basrah, Iraq.

\section{*E-mail: usama_ramadhan@yahoo.com}

\section{ABSTRACT}

Substituted sulfonamides were reacted with thiophene carbaldehydes and piperenal to form Schiff's bases. The structures of synthesized compounds were confirmed by their IR, ${ }^{1} \mathrm{H}$ NMR spectroscopic data and mass spectra.Different necrotizing agents ( $80 \%$ ethanol, $0.2 \mathrm{M} \mathrm{NaOH}$ and $25 \% \mathrm{NaCl}$ ) were used to induced gastric lesions. The compounds were given orally $30 \mathrm{~min}$ before the administration of necrotizing agents. The percentages for compounds to ulcer protective were calculated. Compound 4 was more effective than other compounds and omeprazole itself.Compound 1 was approximate equal to omeprazole activity, and after that compounds 3 and 2 respectively were less active.

Keywords: Substituted sulfonamide, Schiff's bases, gastroprotective, anti-ulcer agent.

$$
\begin{aligned}
& \text { تحضير بعض قواعد شيف جديده ودراسه فعاليتها للوقايه من القرحه المعدية }
\end{aligned}
$$

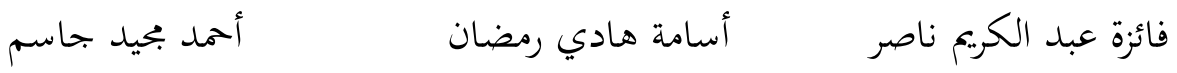

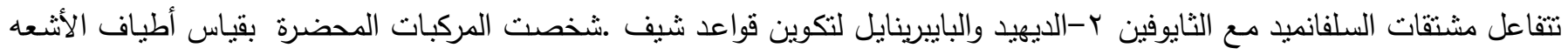

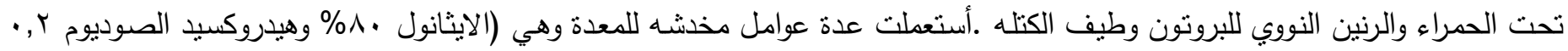

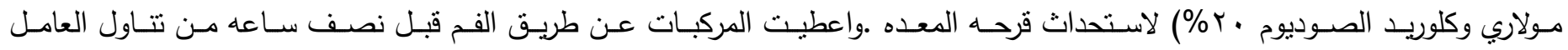




$$
\begin{aligned}
& \text { المخدش.حسبت النسبه المئويه للوقايه من القرحه وكانت النتائج كالتالي المركب ؛ اكثر فعاليه من المركبات الاخرى ومن دواء الامبرازول } \\
& \text { وفعاليه المركب ا مقاربه الى فعاليه الامبرازول بينما أظهر المركبان بو بأقل أقل فعاليه على التوالي. }
\end{aligned}
$$

\section{INTRODUCTION}

Schiff bases have been widely investigated and become one of the research hotspots for a long period of time owing to their strong coordination capability and diverse biological activities, such as antibacterial, antitumor activities, etc.[1-3]. Many Schiff bases are known to be medicinally important and used to design medicinal compounds [4-7]. Moreover, Schiff's bases derived from aromatic amines and aromatic aldehyde have a wide variety of applications in many fields as sulfonamide Schiff's bases have been reported to posses antimicrobial activity[8-15], Schiff base compounds can be classified by their photochromic and thermochromic characteristics[16]. As is known to all, sulfanilamide derivatives have intensively antibacterial actives. However, to the best of our knowledge, Schiff base containing sulfanilamide moieties have been seldom reported[17]. Therefore, investigations of the synthesis and properties of these compounds seem to be a very interesting problem. In view of this study, we describe the synthesis, crystal structure, identification and study their qastropoteective activity of the compounds 1-4.

Peptic ulcer is a common disorder of the entire gastrointestinal tract, they occur mainly in the stomach and the proximal duodenum. The basic physiopathological of gastric ulcer results from an imbalance between some endogenous aggressive factor(s) [hydrochloric acid, pepsin, refluxed bile, leukotrienes, reactive oxygen species (ROS)] and cytoprotective factors, which include the function of the mucus-bicarbonate barrier, surface active phospholipids, prostaglandins (PG), mucosal blood flow, cell renewal and migration, nonenzymatic and enzymatic antioxidants and some growth factors and defensive (mucus secretion, gastric mucosal integrity) factors[18,19]. The objective of the present study was to investigate the antiulcer activity of sulphonyl compounds to cure ulcer as a gastroprotective agents.

\section{Experimental :}

\section{MATERIALS AND METHODS}

Melting points were determined on a capillary melting point apparatus type Thermo Scientific. Infrared spectra were recorded in Shimadzu FTIR8400s spectrophotometer $(\mathrm{KBr})$ and ${ }^{1} \mathrm{H}$ NMR spectra in $\mathrm{DMSO}_{4}$-d6 on Brucker spectrospin-500 $\mathrm{MHz}$, Faculty of science .The mass spectra were measured by using a Agilent technologies 597c University of Tarbiat Modares Tahran.

\section{Synthesis of Schiff's bases}

General method: Equimolar quantities (0.01 mole) of substituted sulfonamide with different aldehydes were dissolved in $15 \mathrm{ml}$ of ethanol. Glacial acetic acid (2 drop) was added to reaction mixture and refluxed for 2-3 h. The content was cooled in ice. The crystalline product was collected by filtration, dried and recrystallized from hexane. Table 1show the physical properties of the prepared compounds. 
Table 1: physical properties of compounds (1-4)

\begin{tabular}{|l||l|l|l||}
\hline No & Name of compounds & Mp c & $\%$ \\
\hline 1 & $\begin{array}{l}\text { 4-(benzo[d][1,3]dioxol-5-ylmethyleneamino) } \\
\text { benzenesulonamide }\end{array}$ & $200-201$ & 80 \\
\hline 2 & $\begin{array}{l}\text { 4-(thiophen-2-ylmethyleneamino) } \\
\text { benzenesulonamide }\end{array}$ & $202-203$ & 95 \\
\hline 3 & $\begin{array}{l}\text { 4-(4-aminophenylsulfonyl)-N-(thiophen-2- } \\
\text { ylmehylene)aniline }\end{array}$ & $213-214$ & 80 \\
\hline 4 & $\begin{array}{l}\text { 4-(4-aminophenylsulfonyl)-N- } \\
\text { (benzo[d][1,3]dioxol-5-ylmethylene)aniline }\end{array}$ & $219-220$ & 85 \\
\hline
\end{tabular}

\section{The Animals}

Wistar albino mice of either sex, approximately of same age, weighing 20-25 g were obtained from Animal House, College of Education, University of Basrah. They were maintained under standard conditions of temperature, humidity and light (12 h dark, $12 \mathrm{~h}$ light) and having free access to food and water. Before testing, the animals were fasted for $36 \mathrm{~h}$ with access to water. The experiments and the procedure of sacrifice (using ether).

\section{Gastric lesions induced by necrotizing agents (Cytoprotection):}

The necrotizing agents were administered in doses of $0.1 \mathrm{ml}$ per $20 \mathrm{~g}$ b.w. (80\% ethanol, $0.2 \mathrm{M}$ $\mathrm{NaOH}$ and $25 \% \mathrm{NaCl}$ ). The compounds were given orally $30 \mathrm{~min}$ before the administration of necrotizing agents in dose $100 \mathrm{mg} / \mathrm{kg}$ dissolved in olive oil and the control group received $0.1 \mathrm{ml}$ olive oil only. The positive control group was received omeprazole at the dose of $30 \mathrm{mg} / \mathrm{kg}$, as a standard drug. One hour after the administration of ethanol and alkalis the rats were sacrificed and examined for lesions in the stomach. The scoring of lesions in the stomach were observed as follows: the patchy lesions of stomach induced by ethanol were scored according to using the following scale: $0=$ normal mucosa; 1 = hyperaemic mucosa or up to 3 small patches; $2=$ from 4 to 10 small patches; $3=$ more than 10 small or up to 3 medium-sized patches; $4=$ from 4 to 6 medium-sized patches; $5=$ more than 6 medium-sized or up to 3 large patches; $6=$ from 4 to 6 large patches; $7=$ from 7 to 10 large patches; $8=$ more than 10 large patches or extensive necrotic zones. The percentages of protective were calculated as equation below [20,21].

\footnotetext{
Control mean ulcer index - test mean ulcer index

$\%$ Protective $=$

\begin{tabular}{ll} 
X 100 \\
\hline
\end{tabular}

Control mean ulcer index
}

\section{Statistical analysis}

Data obtained from the animal experiments was expressed as mean \pm SEM statistical tests including a one-way analysis of variance (ANOVA) significant difference test were used to analyze any differences between the groups that 
were subjected to testing. A p-value of less than 0.01 was considered as being statistically significant.

\section{Results and Discussion}

Sulfonamides Schiff bases are prepared by the acidic catalyzed reaction of thiophen and piperenal with substituted sulfonamides in ethanol as shown in scheme 1 and Table 2

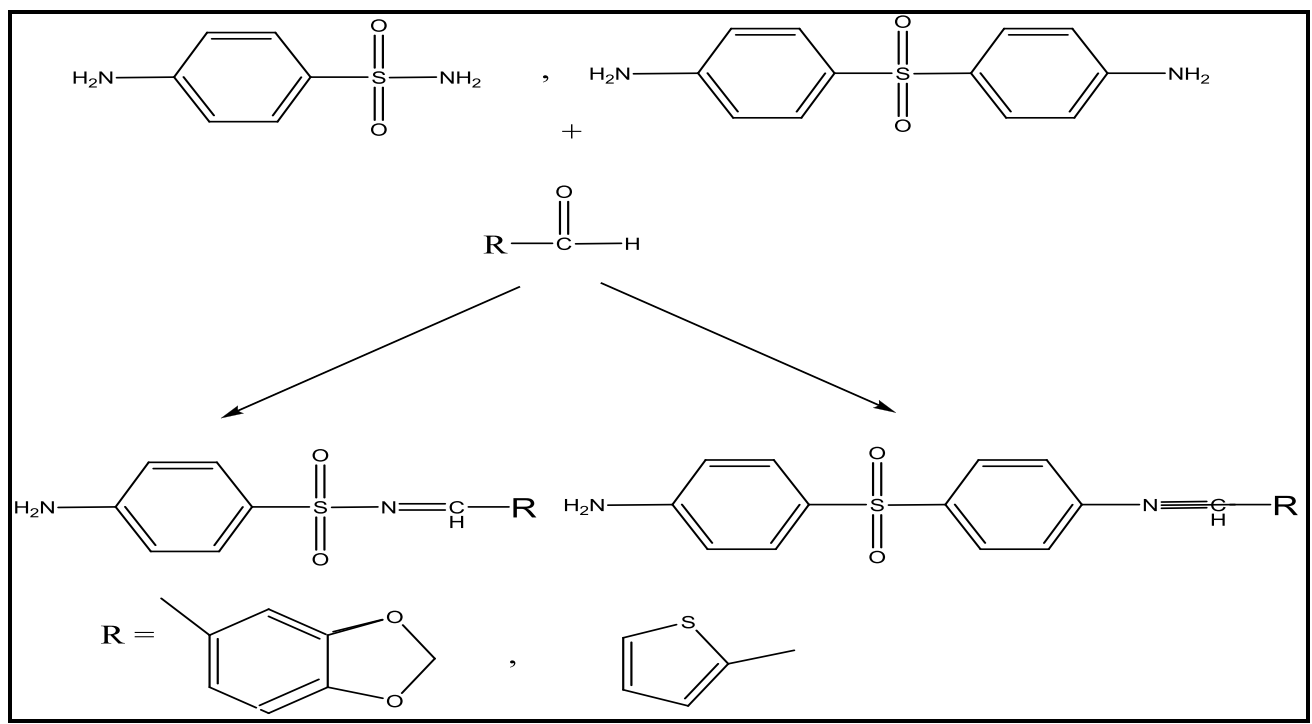

Scheme 1: The rout of svnthesis compounds 1-4

Table (2): Structure of proper compounds 1-4

\begin{tabular}{|l|l|l|}
\hline Sym. & Name of compounds \\
\hline 1 & $\begin{array}{l}\text { 4-(benzo[d][1,3]dioxol-5- } \\
\text { ylmethyleneamino) } \\
\text { benzenesulonamide }\end{array}$ & $\begin{array}{l}\text { 4-(thiophen-2-ylmethyleneamino) } \\
\text { benzenesulonamide } \\
\text { (thiophen-2-ylmehylene)aniline }\end{array}$ \\
\hline 3 & $\begin{array}{l}\text { 4-(4-aminophenylsulfonyl)- } \mathrm{N}- \\
\text { (benzo[d][1,3]dioxol-5- } \\
\text { ylmethylene)aniline }\end{array}$
\end{tabular}




\section{$\underline{\text { IR spectra }}$}

The IR spectra of all compounds are recorded in the solid state using the $\mathrm{KBr}$ disk technique. Selected bands of diagnostic importance are collected in Table (3)

The formation of Schiff bases ( 1-4 ) were indicated by their IR spectra from the appearance of azomethine $\mathrm{C}=\mathrm{N}$ stretching band at 1638-1652 $\mathrm{cm}^{-1}$ combined with the disappearance of IR band in region $1710-1730 \mathrm{~cm}^{-1}$ corresponding to $\mathrm{C}=\mathrm{O}$ group of aldehydes[22,23].The azomethine hydrogen $\mathrm{CH}=\mathrm{N}$ gives bands at $2915-2976 \mathrm{~cm}^{-1}$ .The absorption bands at 1332-1385 $\mathrm{cm}^{-1}$ for $\mathrm{SO}_{2}$, (Asymmetrical str) and 1135-1152 $\mathrm{cm}^{-1}$ for $\mathrm{SO}_{2}$, ( symmetrical str) [24].

Table (3): Selected bands of diagnostic importance from the IR spectra of compounds (1-4).

\begin{tabular}{|l|l|l|l|l|l|l|}
\hline Compounds & $\begin{array}{l}\text { NH-sulph } \\
\mathrm{cm}^{-1}\end{array}$ & $\begin{array}{l}\mathrm{C}-\mathrm{H} \\
\mathrm{Azom} \\
\mathrm{cm}^{-1}\end{array}$ & $\begin{array}{l}\mathrm{Ar}-\mathrm{H} \\
\mathrm{cm}^{-1}\end{array}$ & $\begin{array}{l}\mathrm{C}=\mathrm{C} \mathrm{Ar} \\
\mathrm{cm}^{-1}\end{array}$ & $\begin{array}{l}\mathrm{O}=\mathrm{S}=\mathrm{O} \\
\mathrm{cm}^{-1}\end{array}$ & $\begin{array}{l}\mathrm{C}=\mathrm{N} \\
\mathrm{Azom} \\
\mathrm{cm}^{-1}\end{array}$ \\
\hline 1 & 3448 & 2976 & 3120 & 1450 & $\begin{array}{l}1346 \text { Asy } \\
1152 \text { sym }\end{array}$ & 1645 \\
\hline 2 & 3380 & 2925 & 3105 & 1445 & $\begin{array}{l}1332 \mathrm{Asy} \\
1150 \text { sym }\end{array}$ & 1638 \\
\hline 3 & 3377 & 2915 & 3188 & 1495 & $\begin{array}{l}1385 \mathrm{Asy} \\
1135 \mathrm{sym}\end{array}$ & 1652 \\
\hline 4 & 3365 & 2930 & 3155 & 1498 & $\begin{array}{l}1338 \text { Asy } \\
1138 \text { sym }\end{array}$ & 1648 \\
\hline
\end{tabular}

\section{$\underline{{ }^{1} \text { H-NMR spectra }}$}

The singals observed in the ${ }^{1} \mathrm{H}-\mathrm{NMR}$ spectra of the compounds (Figs 1,2,3,4) are collected in Table(4).The spectra exhibit amultiple at $\delta 6.53-8.72 \mathrm{ppm}$ for the aromatic rings hydrogen [25].The azomethine hydrogen $\mathrm{CH}=\mathrm{N}(1 \mathrm{H})$ appear as singlet of at $\delta 8.44-8.77 \mathrm{ppm}$ [26]. The spectra of compounds 1,2 show asingle with an integration intensity equivalent to two hydrogen at $\delta(6.09$ and 6.10$) \mathrm{ppm}$ respectively corresponding to the $(2 \mathrm{H})$ of the $\mathrm{CH} 2$ group . While the other compounds have a single $(2 \mathrm{H})$ of the $\mathrm{NH} 2$ group at $\delta 6.11-7.30$ ppm [27]. 


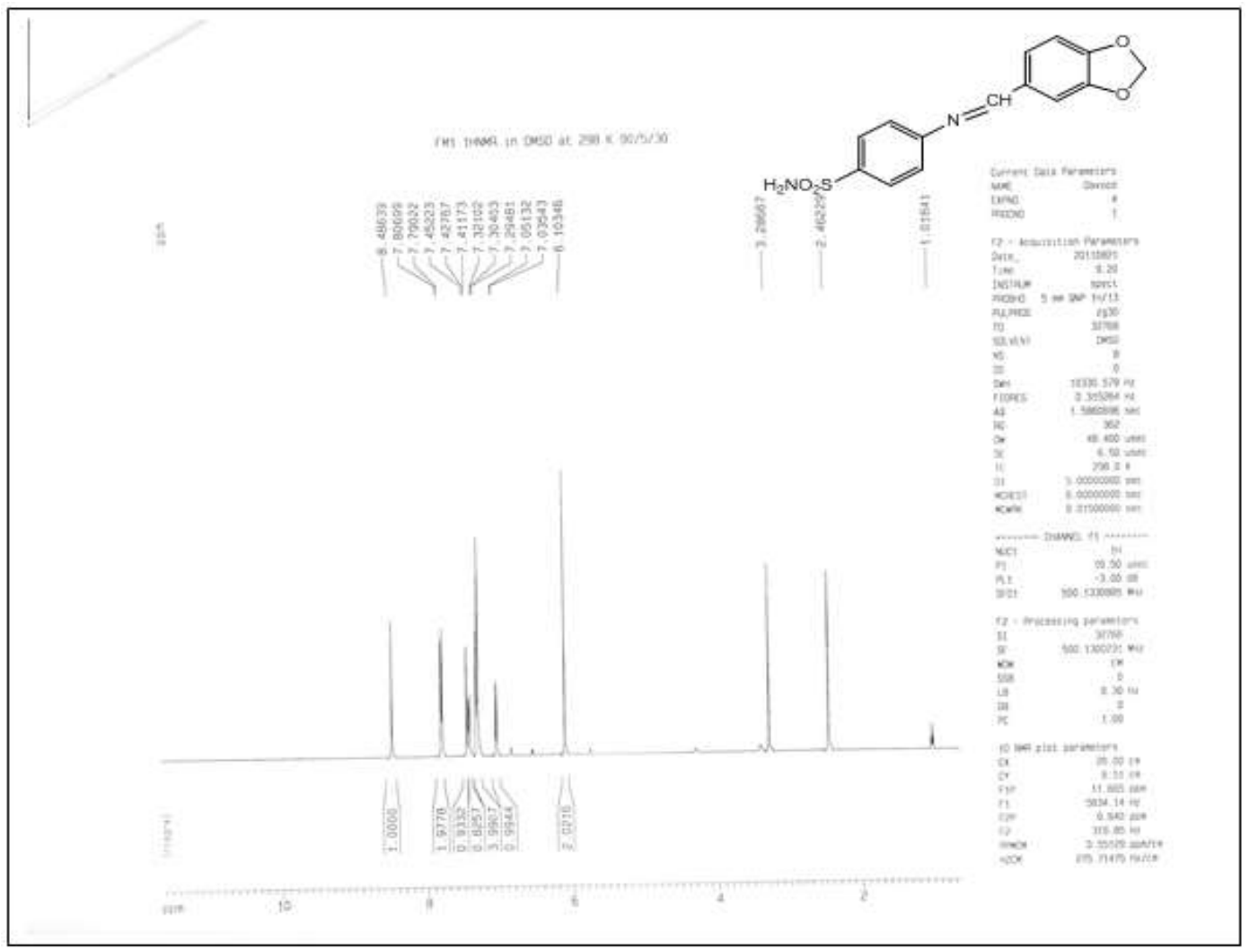

Figure 1: HNMR Spectrum of compound 1

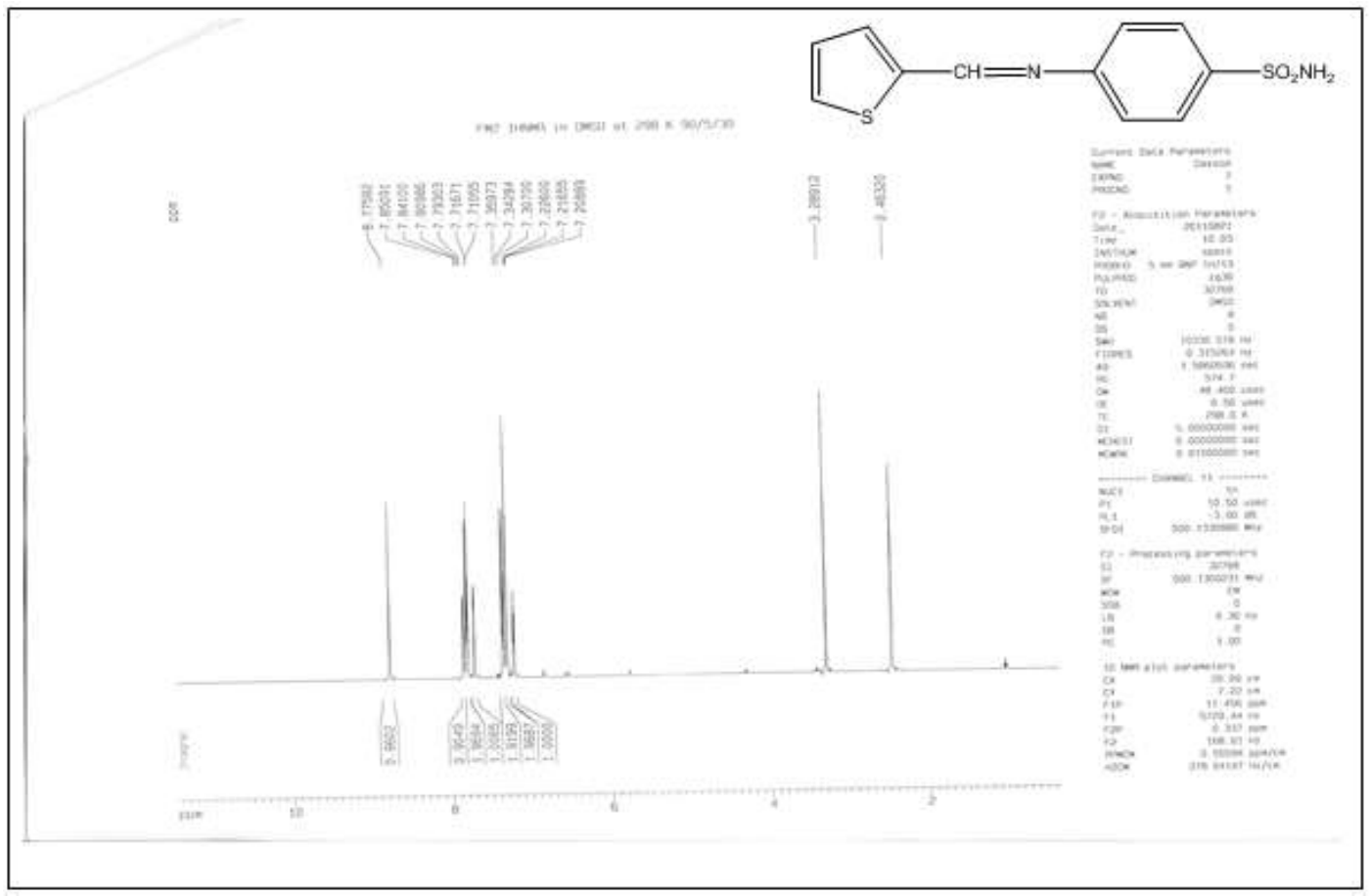

Figure 2: HNMR Spectrum of compound 2 


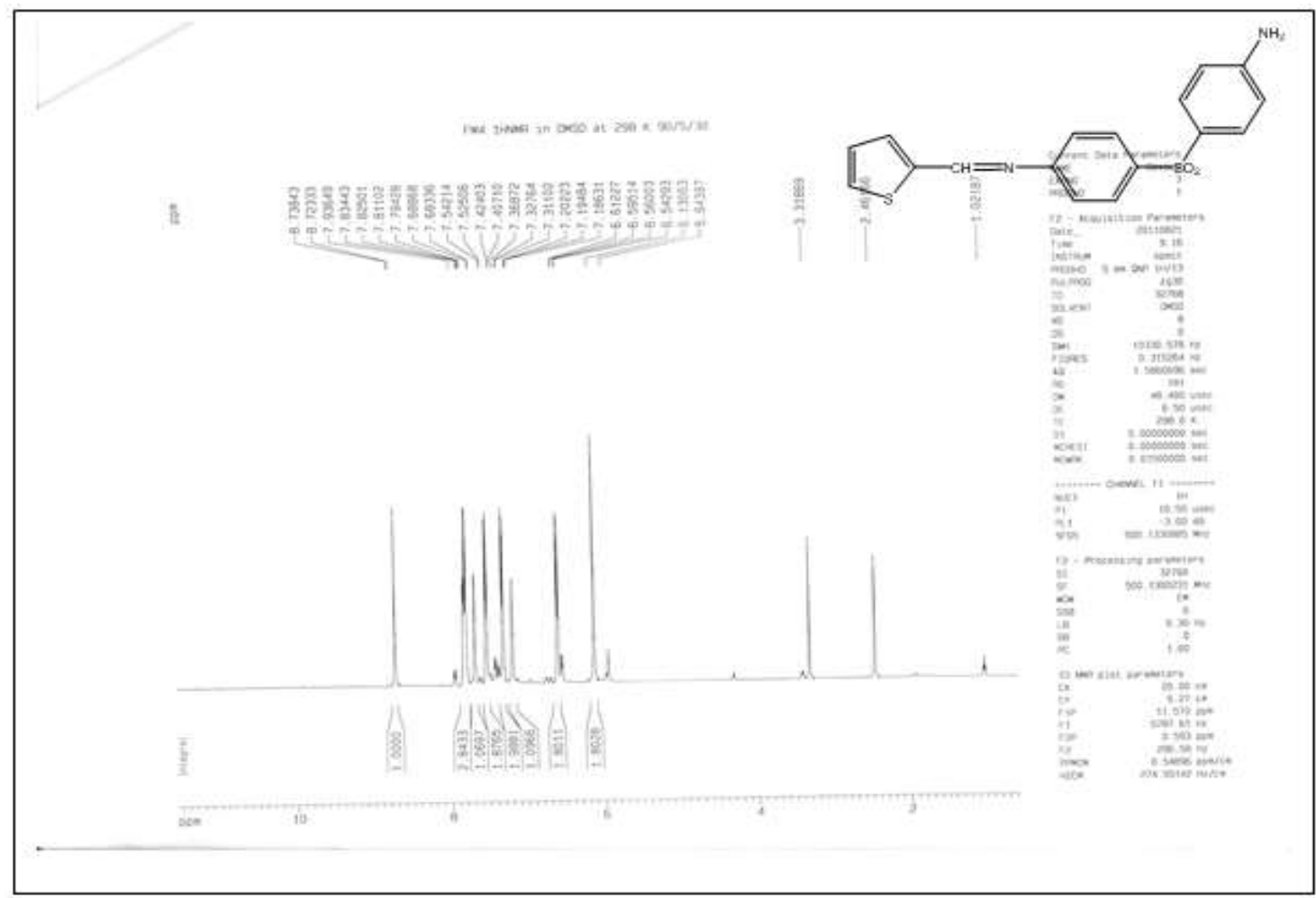

Figure 3: HNMR Spectrum of compound 3

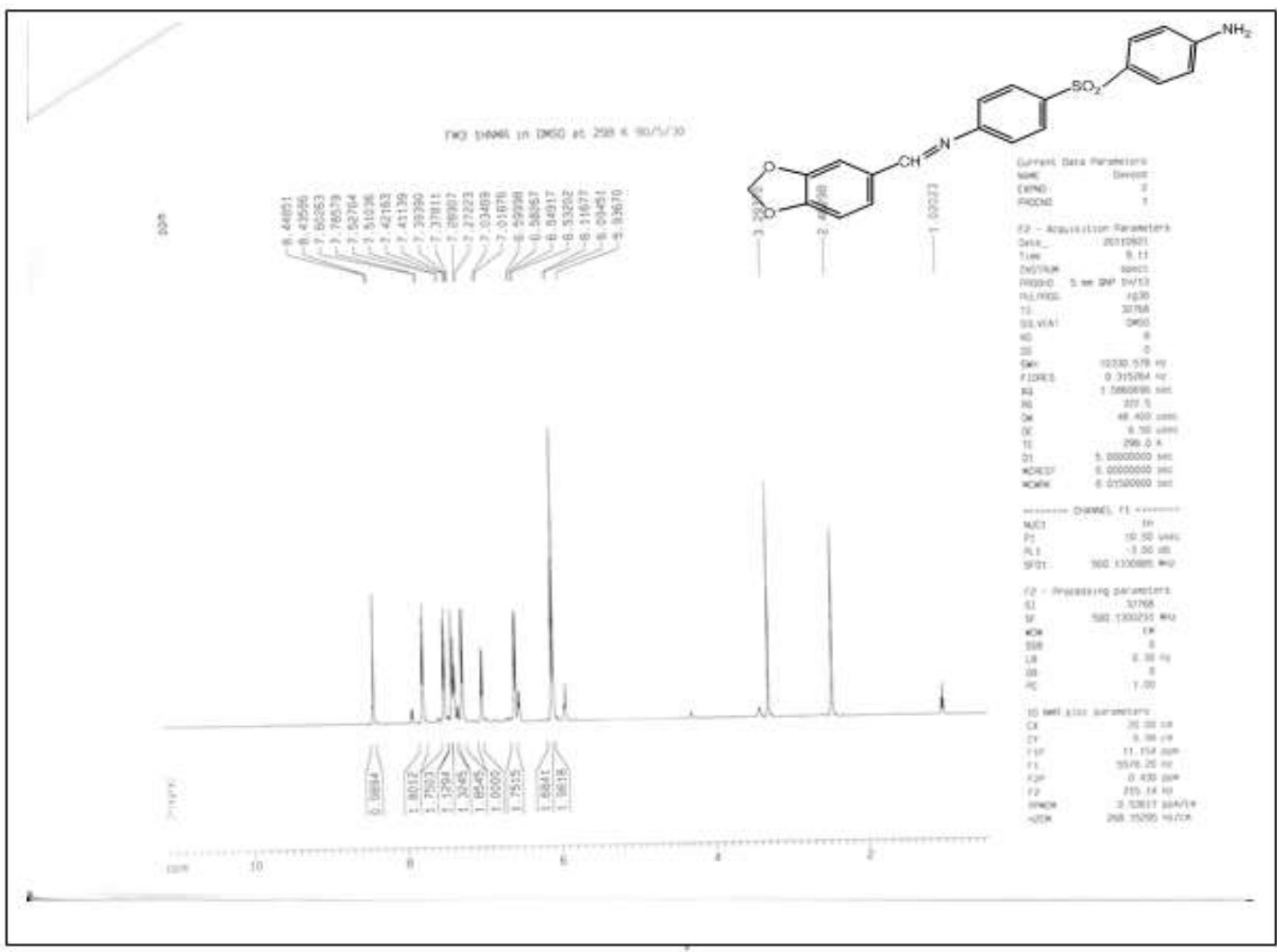

Figure 4: HNMR Spectrum of compound 4 
Table (4): ${ }^{1} \mathrm{H}-\mathrm{NMR}$ spectra of compounds (1-4).

\begin{tabular}{|l|l|l|l|l|}
\hline Compounds & $\mathrm{CH} 2$ & $\mathrm{NH} 2$ & $\mathrm{C}-\mathrm{H}$ Ar & $\mathrm{N}=\mathrm{CH}$ \\
\hline 1 & 6.10 & 7.29 & $7.03-7.80$ & 8.48 \\
\hline 2 & - & 7.30 & $7.20-8.77$ & 8.77 \\
\hline 3 & 6.09 & 6.11 & $6.53-7.80$ & 8.44 \\
\hline 4 & - & 6.13 & $6.54-7.93$ & 8.73 \\
\hline
\end{tabular}

Mass spectra

The mass spectra of Schiff bases (1-4) were measured and the fragmentation routes for these compounds were suggested, as shown in schemes (1-4) .with the parent peaks at $\mathrm{m} / \mathrm{z}$
$304,266,380,341$ respectively. Table (5) shows the import ions that appear in the spectra of these compounds. The base peaks are appeared as shown in (Figs 5-8). The other peaks support the structure of these compounds.

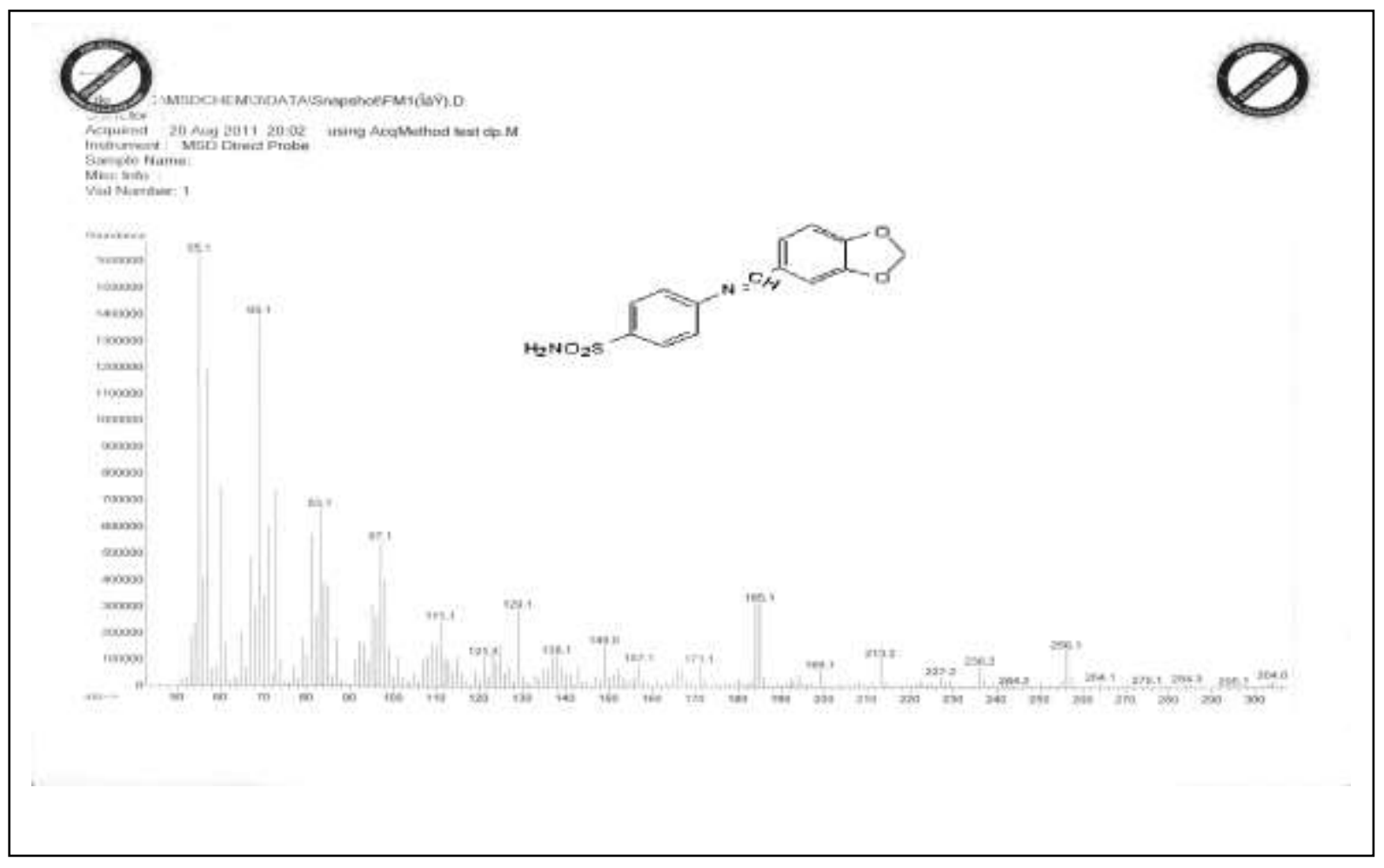

Figure 5: Mass Spectrum of compound 1 


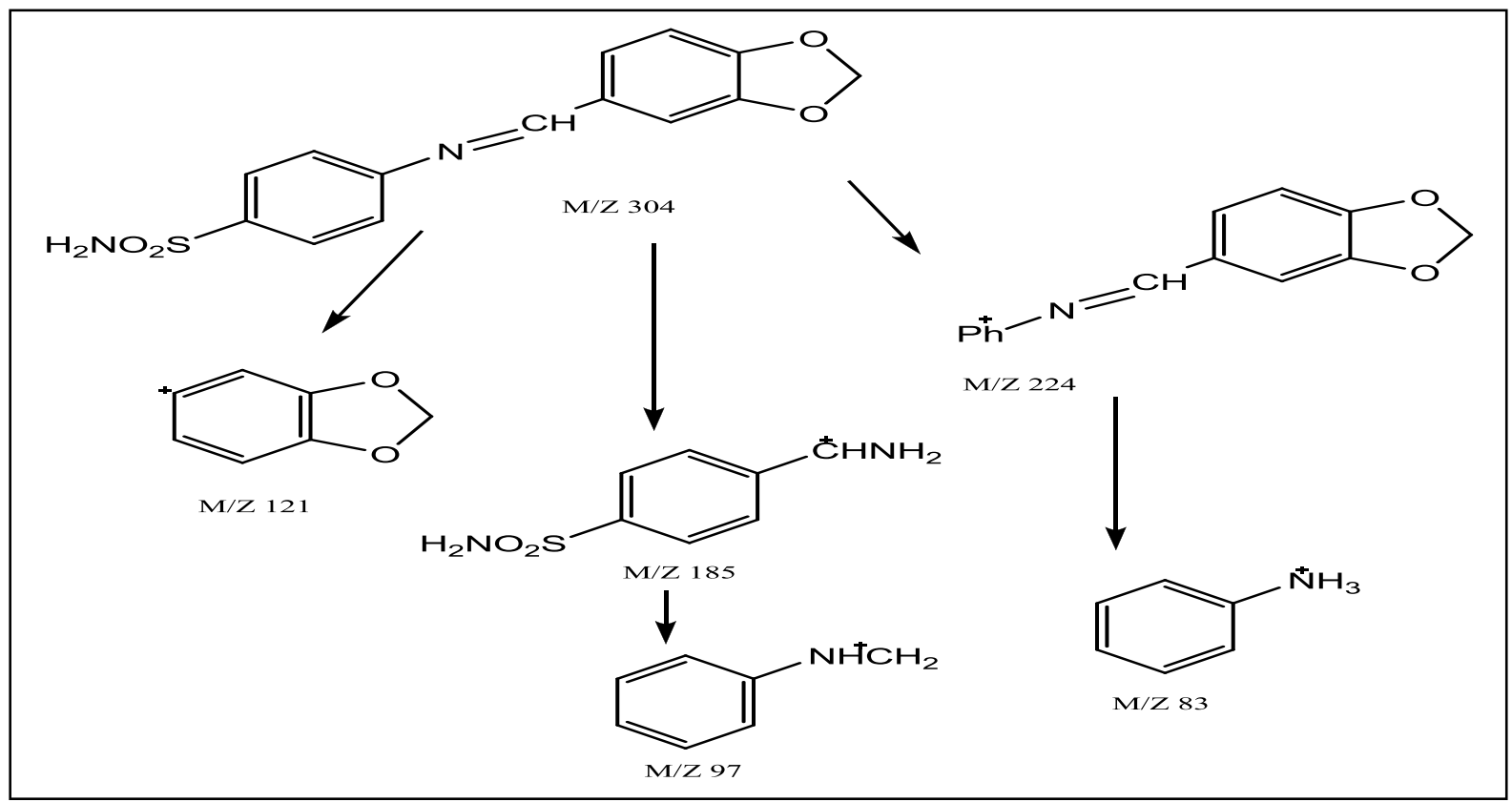

Scheme 2: Fragmentation routes of compound 1

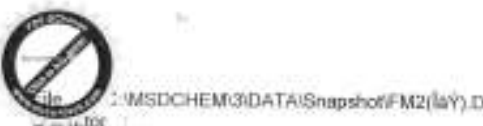

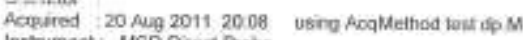

Instrument: MSO Dired Probe

Seemple Name

Mese info

Vial Number: 1

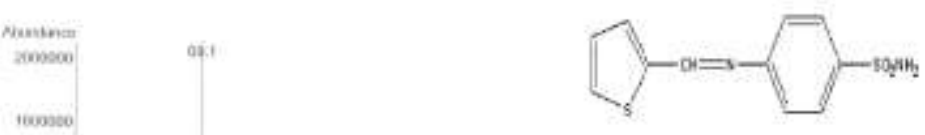

100000

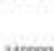

140000:

totoone

socosos
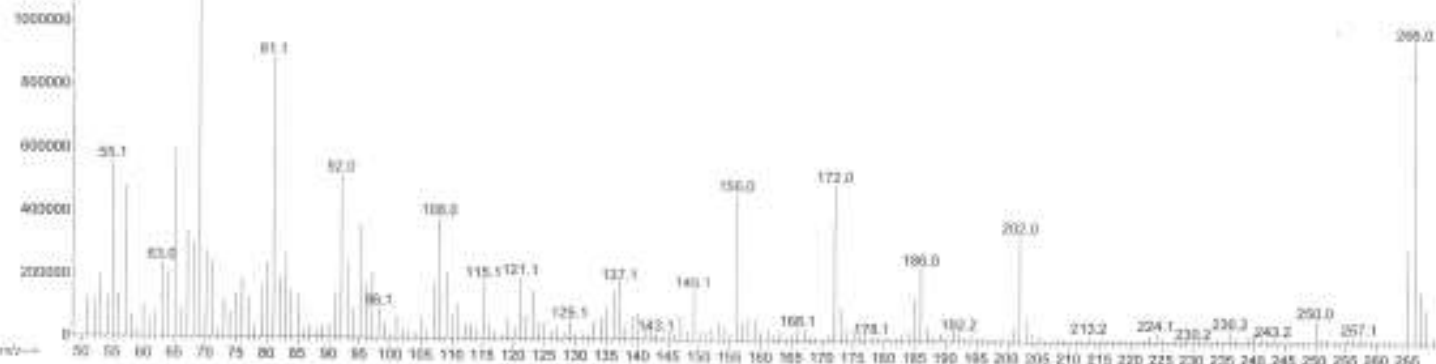

Figure 6: Mass Spectrum of compound 2 


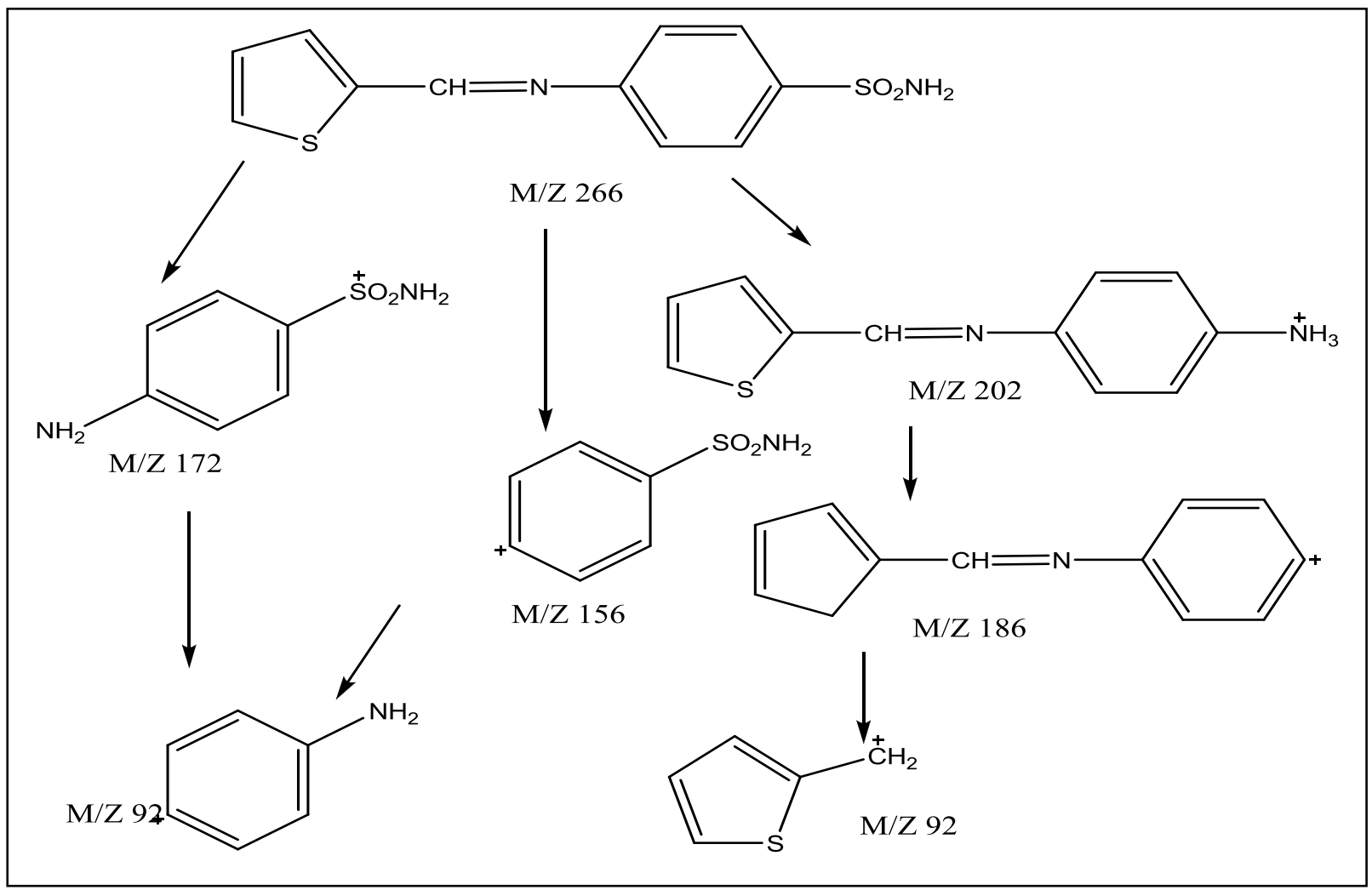

Scheme 3: Fragmentation routes of compound 2

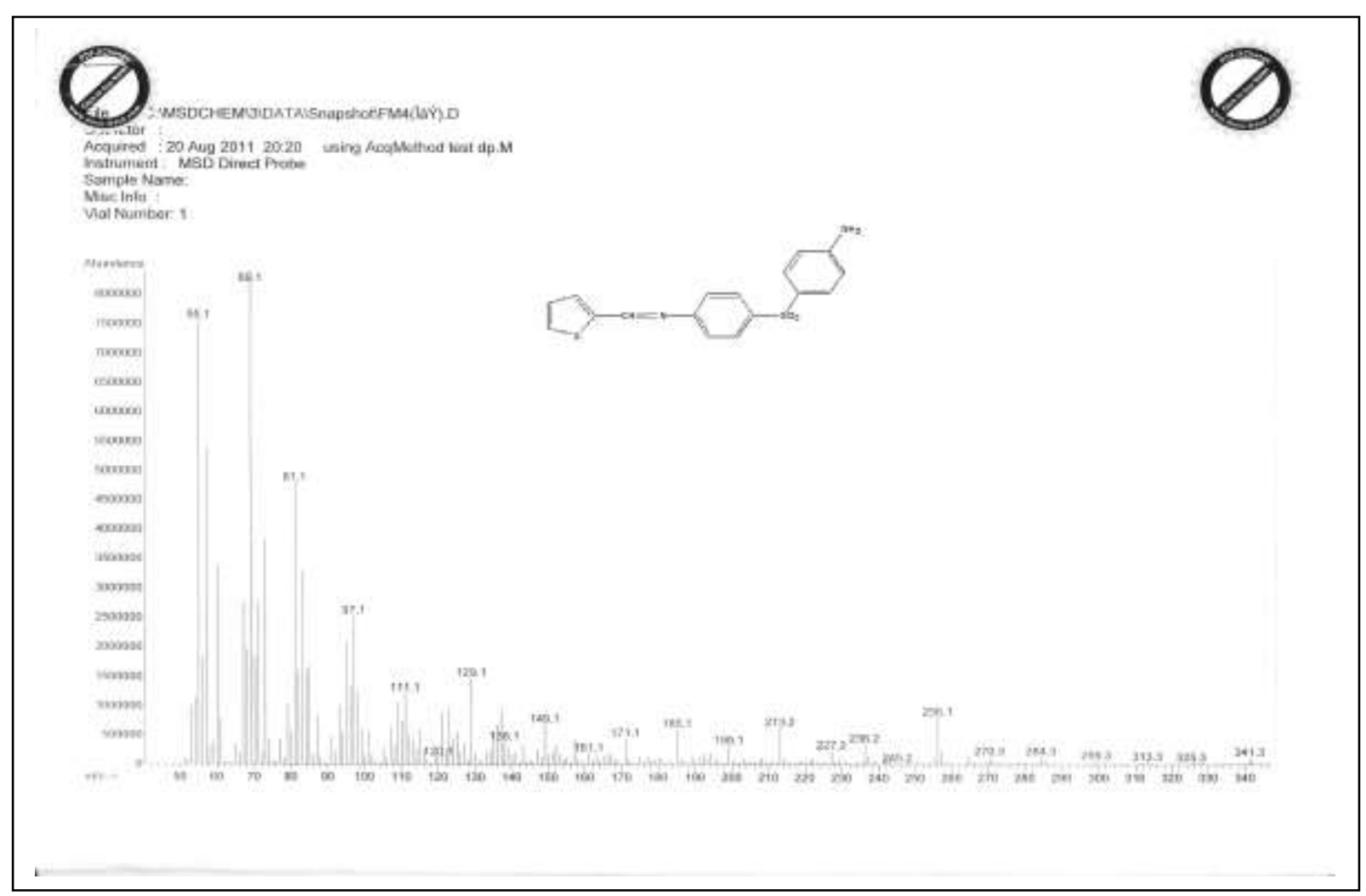

Figure 7: Mass Spectrum of compound 3 


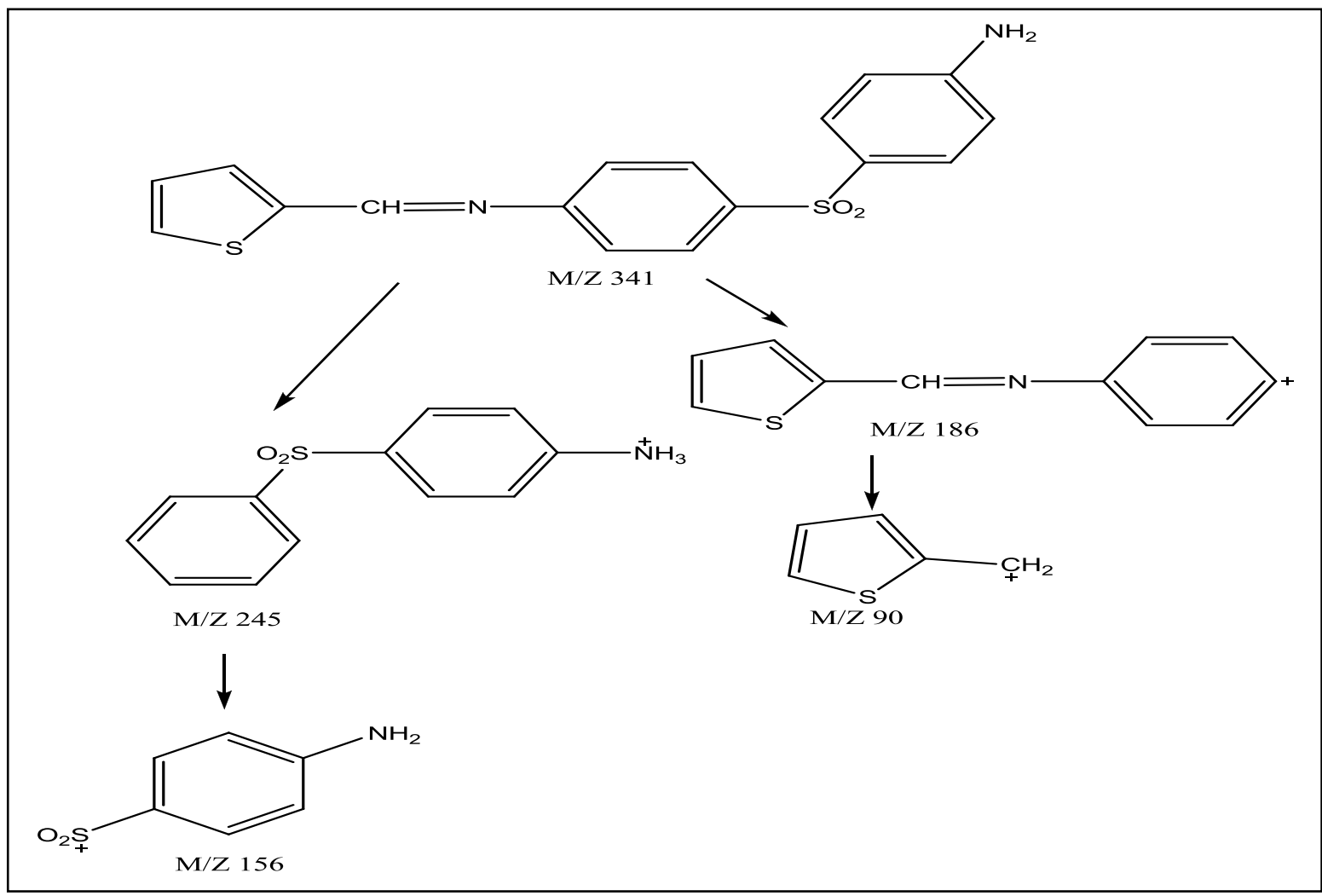

Scheme 4: Fragmentation routes of compound 3

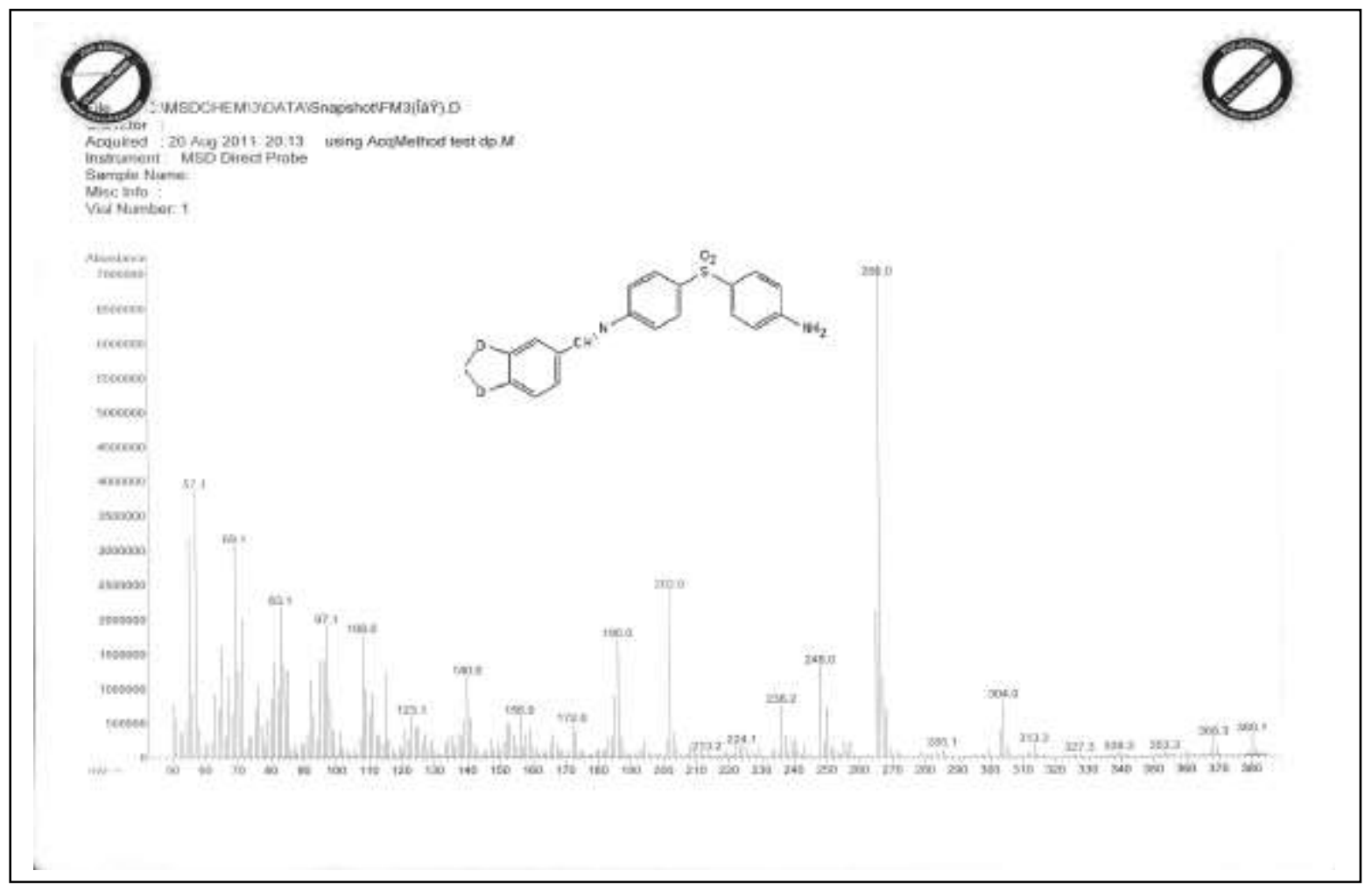

Figure 8: Mass Spectrum of compound 4 


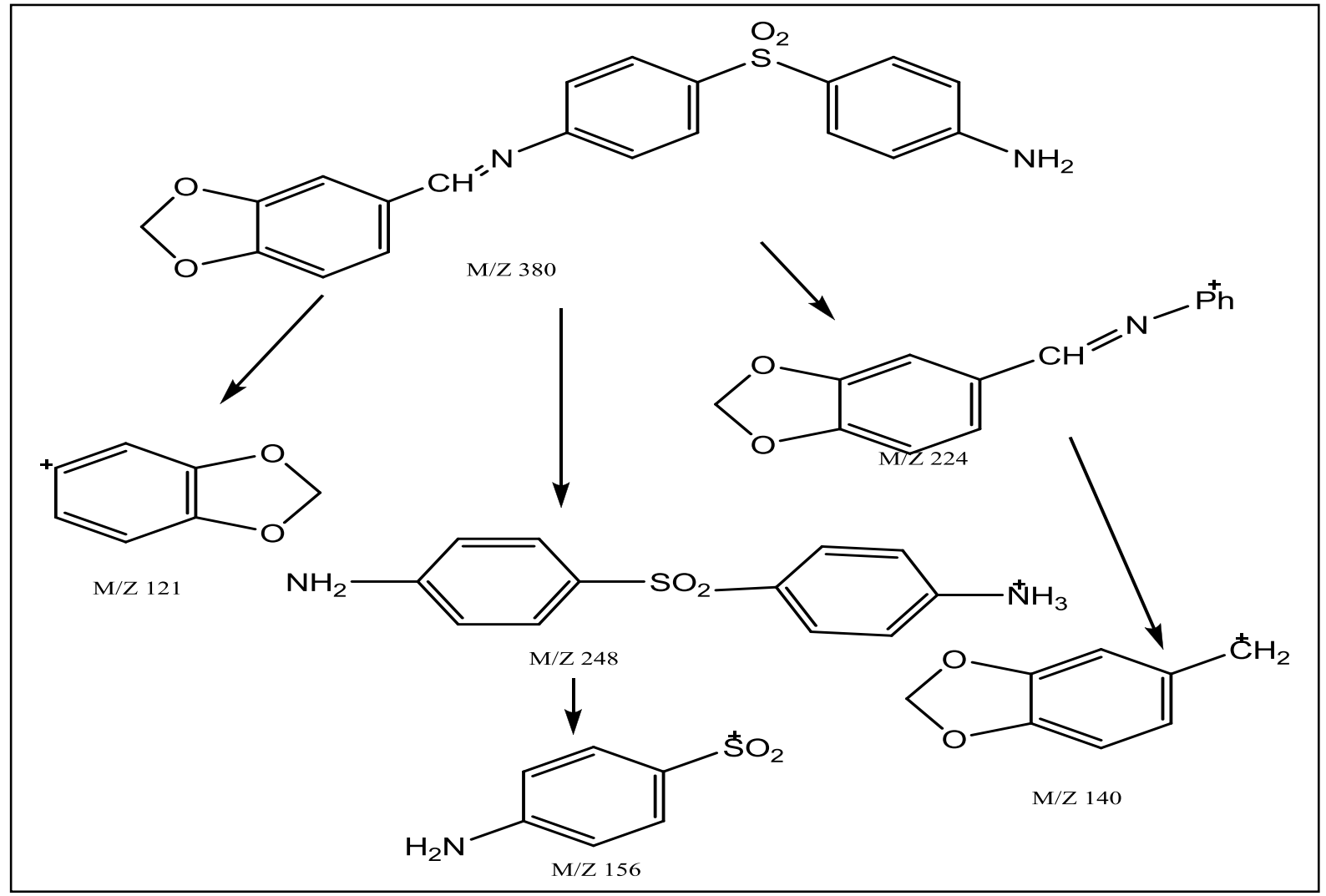

Scheme 5: Fragmentation routes of compound 4

Table (5): Fragmentation pattern of compounds.

\begin{tabular}{|l|l|l|l|l|l|l|l|l|}
\hline $\begin{array}{l}\text { Com } \\
\mathrm{p}\end{array}$ & $\begin{array}{l}\text { Parent } \\
\text { ion }\end{array}$ & $\mathrm{M}^{+}$ & $\begin{array}{l}{ }^{+} \mathrm{PhCH} 2 \mathrm{O} \\
2\end{array}$ & $\begin{array}{l}\mathrm{PH} 2 \mathrm{C} 2 \mathrm{O} 2 \\
\mathrm{~N}^{+}\end{array}$ & $\begin{array}{l}\mathrm{PhN} \\
+\end{array}$ & $\begin{array}{l}{ }^{+} \mathrm{PhNCH} \\
2\end{array}$ & $\begin{array}{l}{ }^{+} \mathrm{PhSO} 2 \mathrm{NH} \\
2\end{array}$ & $\begin{array}{l}{ }^{+} \mathrm{C} 5 \mathrm{H} 4 \\
\mathrm{~S}\end{array}$ \\
\hline 1 & 304 & 121 & 224 & 83 & 97 & 156 & - \\
\hline 2 & 266 & $\begin{array}{l}17 \\
2\end{array}$ & - & - & 83 & 97 & 156 & 92 \\
\hline 3 & 380 & $\begin{array}{l}11 \\
4\end{array}$ & 121 & 224 & 83 & 97 & 156 & - \\
\hline 4 & 341 & $\begin{array}{l}12 \\
9\end{array}$ & - & - & 83 & 97 & 156 & 92 \\
\hline
\end{tabular}

\section{Results of Gastroprotective Activity}

Table (6) shows the effects of the compounds on gastric lesions induced by different necrotizing agents. Compound 4 was more effective than the others and omeprazole itself. Compound 1 was approximate equal to omeprazole activity, and after that compounds 3 and 2 respectively were less active. The percentages for compounds to ulcer protective were shown in Table (7). 
Table 6: Effects of the compounds on gastric lesions induced by necrotizing agents.

\begin{tabular}{|c|c|c|c|}
\hline \multirow{2}{*}{$\begin{array}{l}\text { Treatment } \\
\mathrm{n}=6\end{array}$} & \multicolumn{3}{|c|}{ Ulcer Index (mean \pm S. E.) } \\
\hline & $80 \% \mathrm{EtOH}$ & $0.2 \mathrm{M} \mathrm{NaOH}$ & $25 \% \mathrm{NaCl}$ \\
\hline Control & $7.71 \pm 1.2$ & $7.5 \pm 0.98$ & $7.78 \pm 0.97$ \\
\hline 1 & $2.35 \pm 0.59 * * *$ & $3.3 \pm 0.84 * * *$ & $1.6 \pm 0.65 * * *$ \\
\hline 2 & $4.38 \pm 0.64$ & $4.19 \pm 0.47$ & $5.11 \pm 0.91$ \\
\hline 3 & $3.45 \pm 0.67 *$ & $2.82 \pm 0.68 *$ & $3.74 \pm 0.73^{*}$ \\
\hline 4 & $1.13 \pm 0.76 * * *$ & $0.62 \pm 0.44 * * *$ & $0.91 \pm 0.37 * * *$ \\
\hline Omeprazole & $2.24 \pm 0.85^{* * *}$ & $2.43 \pm 0.72 * * *$ & $2.09 \pm 0.81 * * *$ \\
\hline
\end{tabular}

Table 7: The percentages for compounds of ulcer protective

\begin{tabular}{|r|r|r|r|}
\hline $\begin{array}{r}\text { Treatment } \\
\mathrm{n}=6\end{array}$ & $80 \% \mathrm{EtOH}$ & $0.2 \mathrm{M} \mathrm{NaOH}$ & $25 \% \mathrm{NaCl}$ \\
\cline { 2 - 4 } & 69.5 & 56.0 & 79.4 \\
\hline 2 & 43.1 & 44.1 & 34.3 \\
\hline 3 & 55.2 & 62.4 & 51.9 \\
\hline 4 & 85.3 & 91.7 & 88.3 \\
\hline Omeprazole & 70.9 & 67.6 & 73.1 \\
\hline
\end{tabular}

\section{Discussion}

Gastric ulcers result from an imbalance involving gastric protection and aggressive factors. Gastric protection depends on a number of factors such as the release of prostaglandin E2 (PGE2), bicarbonate secretion, gastric mucus production and the regulation of gastric mucosal blood flow. Factors leading to gastric offensives are the hyper secretion of $\mathrm{HCl}$ or pepsin. Ethanol is well known to induce gastric ulcers via multi-factorial mechanisms such as the impairment of gastric defensive factors like mucus dissolution or by increasing offensive factors such as acid secretion or gastrin release [28]. There are many products in the market for the treatment of gastric ulcer, including antacids, proton pump inhibitors, anticholinergics and histamine $\mathrm{H}_{2-}$ antagonists[29].The pepsin is one of three principal protein degrading, or proteolytic, enzymes in the digestive system, the other two being chymotrypsin and trypsin and $\mathrm{HCl}$ are important for formation of pylorus ligated ulcers. The gastric protective effect of the compounds is related to cytoprotective properties; it is possible that the inhibitory effect is due the solubility of compounds in olive oil, associated with anti-ulcerogenic activity. The ethanol administration show significant reduction in non-protein sulfhydryls (NP-SH) content of gastric mucosa [30]. This result suggested that compounds increase the mucosal sulfhydryl groups content to protected the stomach.

\section{REFERENCES}

(1) Wang, N.; Li, J. P.; Pu, Y. L. Chin. J. Struct. Chem. 2007, 26, 547-550.

(2) Yu, Q.; Zhu, L. G.; Bian, H. D.; Deng, J. H.; Yang, X. E.; Guo, G. Q.; Liang, H. Chin. J. Struct. Chem. 2005, 24, 1271-1275.

(3) Zhou, Y. Z.; Li, J. F.; Tu, S. J.; Zhang, M. Chin. J. Struct. Chem. 2005, 24, 11931197.

(4) Tarafder, M. T. H.; Khoo, T. T.; Crouse, K. A. Polyhedron 2002, 21, 2691-2697. 
(5) Belwal, S. S.; Fahrmi, N.; Singh, R. V. Indian J. Chem. Sect A 1999, 38A, 596-598.

(6) Ren, S. J.; Wang, R.; Komatsu, K. J. Med. Chem. 2002, 45, 410-417.

(7) Seshaiah, K. S.; Muniyandy, S.; Atmakuru, R. Eur. J. Med. Chem. 2001, 36, 615-619. (8) Patel A, Bari S, Telele G, Patel J, Sarang. Iran. J. Pharm. Sci. 2006; 4: 249-254.

(9) Parekh J, Inamdhar P. J. Serb. Chem. Soc. 2005; 70(10):1163-1167.

(10) Singh UK, Pandeya SN, Singh A, Srivastava BK, Pandey M. International Journal of Pharmaceutical Sciences and Drug Research. 2010; 2(2): 151-154.

(11) Panneerselvam P, Rather BA, Reddy DRS, Kumar NR. European Journal of Medicinal Chemistry. 2009; 44(5):2328-2333.

(12) Singh UK, Pandeya SN, Jindal S, Pandey M, Srivastava BK, Singh A. Der Pharma Chemica. 2010; 2(2): 392-399.

(13)Manikpuri AD. Research Journal of Pharmaceutical, Biological and Chemical Sciences. 2010; 1(2):21-27.

(14)Kumar S, Niranjan MS, Chaluvaraju KC, Jamakhandi CM, Kadadevar D. Journal of Current Pharmaceutical Research. 2010; 01: 39-42.

(15)Iqbal N, Iqbal J, Imran M. Journal of Scientific Research. 2009; 19(1):15-19.

(16)Siddiqui, H. L.; Iqbal, A.; Ahmad, S.; Weaver, G. W. Molecules 2006, 11, 206-211.

(17) Xu, H. F.; Zhang, S. H.; Jiang, Y. M.; Zhong, X. X.; Gao, F. Chin. J. Struct. Chem. 2004, 23, 808-811.

(18) Umamaheswari M, Asokkumar K, Rathidevi R, Sivashanmugam AT, Subhadradevi V and Ravi TK. Antiulcer and in-vitro antioxidant activities of Jasminum grandiflorum L. J. Ethnopharmacol. (2007) 110: 464-470.

(19) Valim Araujo D A, Takayama C, De-Faria F M, Socca E A, Dunder R J, Manzo L P, Luiz-Ferreira A and Alba R. M. SouzaBrito A R, Gastroprotective effects of essential oil from Protium heptaphyllum on experimental gastric ulcer models in rats,
Brazilian Journal of Pharmacognosy, 2011, 21(4): 721-729.

(20) Alqasoumi S, Al-Yahya M, Al-Howiriny T and Rafatullah S, Gastroprotective effect of radish "raphanus sativus" 1. On experimental Gastric ulcer models in rats, Farmacia, 2008, LVI (2). 204-214.

(21) Giri M A, Bhalke R D and Pal S C, Gastroprotective effect of hydroalcoholic leaves extract of Pongamia pinnata, International Journal of Pharma and Bio Sciences, 2010, 1 (3), 1-6.

(22) Raval J.P. , Akhaga T.N. and Patel H.V. ;Inter,J,Pharm,Res, 1(2),62-71,(2009)

(23) Tiongha S., Khoon L. and Foowin Y. , mol bank,582,(2008).

(24) Dmehta P., Psengar N. and Vsubrahmayam E. ,Indian ,J,pharm,Sci,68,103,(2006).

(25) Vora J.J. , Vasava S.B. and Parmar K.C. ,E,J,Chem,6,4,1205-1210 (2009).

(26) Issa R.M., Khedr A.M. and Rizk H. ,J,Chin,Chem,Soci,55,875-884,(2008).

(27) Thilagavathi R. and Kavitha H.P. ;mol bank,m589(2009).

(28) Metowogo K, Eklu-Gadegbeku K, Agbonon A, Aklikokou K A and Gbeassor M, Gastroprotective Effect of Hydroalcoholic Extract of Aloe buettneri, Iranian Journal of Pharmaceutical Research, 2011, 10 (1): 69-74.

(29) Khatib N, Angel G, Nayna H, Joshi Rajesh Kumar J R, gastroprotective activity of the aqueous extract from the roots of daucus carota L in rats, IJRAP 2010, 1 (1) 112119.

(30) Saravanan S, Dhasarathan P, Indira V and Venkatraman R, Gastro protective and antioxidant activity of Solanum nigrum Linn. Against aspirin and cold restraint stress induced ulcerated rats, Research journal of immunology, 2011, 4 (1), 1-11. 